\title{
Kebijakan Legislatif tentang Pidana Denda dan Penerapannya dalam Upaya Penanggulangan Tindak Korupsi
}

\author{
Syaiful Bakhri \\ Fakultas Hukum Universitas Muhammadiyah Jakarta \\ Jl. K.H. Ahmad Dahlan Jakarta \\ Bahri_msb@yahoo.com
}

\begin{abstract}
This research focuses the issue of legislative policy of fine and its implementation in effort to overcome corruption. By using normative and qualitative legal method, this research revealed the following facts. First, implementation of fine in positive law of Indonesia not accordance with the punishment objectives as regulated in Criminal Act besides Indonesian Civil Code. In fact, fine seems like ineffective sanction. So, even though there are lots regulation about fine which mostly imposing high fine to defender, but it cannot creates preventive and deterrence effect. Second, effectiveness of fine implementation in court practice still questionable. In corruption case, sometime judges imposed high imprisonment to offender and supplemented with lower fine. In imposing fine, mount of fine is under the minimum standard which regulated in Corruption Act. Third, fine must be formulated with rational, exact and efficient ways. Related with the effort to overcome corruption, fine must be maximized to punish offender to achieve detterence effect.
\end{abstract}

Key words: Fine, corruptions, legislatife policy

\begin{abstract}
Abstrak
Penelitian ini difokuskan pada persoalan kebijakan legislasi mengenai pidana denda dan implementasinya dalam rangka untuk mengatasi persoalan korupsi. Dengan menggunakan metode penelitian normatif dan kualitatif ditemukan hal-hal sebagai berikut: Pertama, implementasi pidana dalam hukum positif Indonesia tidak sesuai dengan tujuan pemidanaan sebagaimana diatur dalam KUHP, dalam kenyataannya, pidana denda tidak berjalan efektif, walaupun banyak aturan mengenai pidana denda yang mengenakan pidana denda yang tinggi kepada pelaku kejahatan, tetapi tidak mampu menciptakan efek pencegahan dan efek jera. Kedua, keefektifan penerapan pidana denda masih menjadi hal yang dipertanyakan. Dalam kasus korupsi hakim, hakim lebih cenderung memberikan pidana penjara yang tinggi dan hanya mengenakan pidana denda yang relatif rendah. Ketiga, formulasi kebijakan pidana denda harus dilakukan secara dilakukan secara efisien, pasti, dan rasional. Terkait dengan upaya penanggulangan tindak pidana korupsi, pidana denda harus dikenakan semaksimal mungkin untuk menimbulkan efek jera.
\end{abstract}

Kata kunci : Pidana denda, korupsi, kebijakan legislatif 


\section{Pendahuluan}

Pidana denda sudah lama dikenal secara luas di dunia, tetapi kajian mengenai hal ini masih sangat sedikit. Para ahli hukum mempunyai pandangan yang berbeda tentang pidana denda dalam keseluruhan sistem pidana, ${ }^{1}$ khususnya apabila dihubungkan dengan pidana penjara. Pandangan-pandangan tersebut membentuk suatu sikap yang saling bertolak belakang antara pidana penjara dan pidana denda.

Terhadap pidana penjara, ${ }^{2}$ para ahli hukum pidana cenderung meminimalisasi penggunaannya. ${ }^{3}$ Sebaliknya, pidana denda justru ingin dimaksimalisasi. ${ }^{4}$ Pidana penjara seringkali dianggap terlalu berat jika dibandingkan dengan pidana denda. Pidana denda akan diusahakan semaksimal mungkin dan menjadi prioritas utama sebelum ditambah dengan pidana penjara. ${ }^{5}$ Becker dan Posner mengemukakan bahwa penggunaan pidana denda mempunyai beberapa keuntungan dibandingkan dengan pidana penjara. Penggunaan pidana denda dapat menghindari biaya-biaya sosial yang dikeluarkan untuk memelihara penjara, menghindari penahanan yang tidak perlu, dan menghindari penyia-nyian modal manusia yang tidak berguna di dalam penjara. ${ }^{6}$ Minimalisasi pidana penjara ditandai dengan tiga gejala utama, yaitu perkembangan tujuan-tujuan pemidanaan, ${ }^{7}$ modifikasi eksekusi pidana penjara, dan upaya pencarian pidana alternatif. ${ }^{8}$

${ }^{1}$ Pidana denda adalah suatu hukuman, berdasarkan ketentuan KUHP wajib membayar sejumlah uang yang ditetapkan dalam putusan pengadilan kepada negara, tidak dapat mendayagunakan keberatan atau perlawanan dalam konteks hukum keperdataan terhadap Negara, et. seq. Lihat dalam Jan Remmelink, Hukum Pidana: Komentar atas Pasal-Pasal Terpenting dalam Kitab Undang-Undang Hukum Pidana Belanda dan Padanannya Dalam Kitab Undang-Undang Hukum Pidana Indonesia, PT Gramedia, Jakarta, 2003, hlm. 485.

${ }^{2}$ E.Y Kanter dan S.R Sianturi, Asas-Asas Hukum Pidana di Indonesia dan Penerapannya, Alumni, Jakarta, 1982, hlm. 467.

${ }^{3}$ Minimalisasi penggunaan pidana penjara dewasa ini berbagai upaya dilakukan untuk melakukan reformasi dan renovasi terhadap penggunaan pidana penjara sebagai salah satu sarana utama sifat represif dari hukum pidana. Kecenderungan ini tampak pada berbagai sistem hukum negara-negara di dunia, khususnya pada sistem hukum Anglo Saxon dan sistem hukum Eropa Kontinental. Lihat Muhari Agus Santoso, Paradigma Baru Hukum Pidana, Averroes Press, Malang, 2002, hlm. 53. Lihat juga rekomendasi hasil Kongres PBB ke-2 (1960) di London, mengenai Pencegahan Kejahatan dan Pembinaan Pelanggaran Hukum berkaitan dengan Standard Minimum Rules, yang isinya membatasi atau mengurangi penggunaan yang luas dari pidana penjara pendek.

${ }^{4}$ Perubahan pandangan ahli hukum tentang pidana penjara telah membawa pemikiran ke arah penggantian hukuman penjara dengan penggunaan denda.

${ }^{5}$ Joel Waldfogel, "Are Fines and Prison Terms Used Efficiently? Evidence on Federal Fraud Offenders," Journal of Law and Economics, Volume 35, April, 1995, hlm. 107.

${ }^{6}$ Steven D. Levitt, "Incentive Compatibility Constraints as an Explanation for the Use of Prison Sentences Instead of Fines," International Review of Law and Economics, Volume 17, Juni 1997, hlm. 179-180.

${ }^{7}$ Perkembangan tujuan pemidanaan, belum pernah dirumuskan, karena hukum pidana yang berlaku di Indonesia sekarang ini merupakan peninggalan kolonial. Rezim kolonial berpandangan tidak perlu untuk merumuskan tujuan pidana dan pemidanaan karena hukum pidana diciptakan dengan tujuan utama melindungi kepentingan- 
Sikap para ahli hukum pidana untuk memaksimalisasi pidana denda sedikitnya tercermin pada tiga paradigma utama, yaitu diterimanya korporasi sebagai subjek tindak pidana, pidana denda dalam hukum administratif, model pengancaman pidana denda dan model eksekusi pidana denda. ${ }^{9}$ Perkembangan pemikiran para ahli hukum pidana dan ahli filsafat pemidanaan mengenai tujuan yang harus dijadikan pedoman dalam menyelenggarakan pemidanaan mencerminkan sikap untuk sedapat mungkin membatasi penggunaan pidana penjara. Pidana penjara yang oleh para abolisionis dikatakan sebagai sarana utama dan lambang dari pemidanaan, ${ }^{10}$ telah dijadikan pangkal tolak pengkajian mengenai tujuan pemidanaan. ${ }^{11}$

Formulasi pidana denda dalam hukum pidana positif mulai mengalami kemajuan. Hal ini dapat dilihat dengan diterimanya korporasi sebagai subjek tindak pidana dalam hukum Indonesia. ${ }^{12}$ Terutama juga sejak digunakannya ketentuan pidana yang mencantumkan sanksi denda oleh legislator, yaitu sejak korporasi sebagai badan hukum dipandang dapat melakukan tindak pidana sebagaimana dalam Pasal 15 ayat (1) UU Darurat No. 7 Tahun 1955 tentang Tindak Pidana Ekonomi. Selanjutnya disingkat (UUTPE). Kemudian beberapa ketentuan undangundang menegaskan bahwa korporasi bukan hanya sebagai pelaku, tetapi juga dapat dipertanggungjawabkan dalam hukum pidana, seperti Penjelasan Pasal 5 UU No. 4 Tahun 1982 tentang Lingkungan Hidup. Hal yang sama kembali ditegaskan dalam

kepentingan pemerintah kolonial. Lihat Muhari Agus Santoso, Op.Cit., hlm. 56-57. Kemudian seiring dengan perkembangan hukum, banyak muncul pandangan terhadap perlunya perumusan tujuan pemidanaan, antara lain: Sudarto, Hukum Pidana dan Pembangunan Masyarakat, Sinar Baru, Bandung:, 1983, hlm 70, bandingkan dengan Surat Edaran Mahkamah Agung Republik Indonesia (SEMARI) Tanggal 3 September 1975 yang mencerminkan pemidanaan yang bersifat retributif. Lihat juga RUU KUHP 2008, (1) Pemidanaan bertujuan: a. mencegah dilakukannya tindak pidana dengan menegakkan norma hukum demi pengayoman masyarakat; b. memasyarakatkan terpidana dengan mengadakan pembinaan sehingga menjadi orang yang baik dan berguna; c. menyelesaikan konflik yang ditimbulkan oleh tindak pidana, memulihkan keseimbangan dari mendatangkan rasa damai dalam masyarakat; d. membebaskan rasa bersalah pada terpidana. (2) Pemidanaan tidak dimaksudkan untuk menderitakan dan merendahkan martabat manusia.

${ }^{8}$ Muladi dan Barda Nawawi Arief, Teori-Teori dan Kebijakan Pidana, Alumni, Bandung. 1992, hlm. 177-178.

${ }^{9}$ Sutherland dan Cressey, The Control Crime, New York, 1960, hlm. 276, dikatakan dasar-dasar pembenaran kecenderungan penggunaan pidana denda, antara lain: Pertama, denda adalah hal yang paling mudah dilakukan dan sepenuhnya dapat diterima oleh segala bentuk hukuman. ; Kedua, denda adalah hukuman yang paling ekonomis; Ketiga, denda dengan mudah dapat dibagi-bagi dan dapat disesuaikan dengan besarnya pelanggaran yang telah dilakukan; Keempat, dengan membayar denda maka pelanggar tidak terbebani dengan stigma publik dan rasa malu; Kelima, denda mempengaruhi kepentingan manusia yang paling umum dan denda merupakan pemasukan bagi negara.

${ }^{10}$ John R Blad, Hans van Mastright dan Niels A Uildriks, Social Problem and Criminal Justice, Medelingen van het Juridisch Institut van de Erasmus Universuteit Rotterdam, Rotterdam, 1987, hlm. 8.

${ }^{11}$ Andi Hamzah, Sistem Pidana dan Pemidanaan di Indonesia dari Retribusi ke Reformasi, Pradnya Paramita, Jakarta, 1986, hlm. 15-16.

${ }^{12}$ Pasal 47 RUU KUHP Tahun 2008. 
Pasal 46 UU No. 23 Tahun 1997 tentang Lingkungan Hidup. Ketentuan yang sama juga terdapat dalam Pasal 6 ayat (1), 7 ayat (1), 10 ayat (1) UU No. 9 Tahun 1985 tentang Perikanan. Prinsip ini juga diikuti oleh Pasal 21 ayat (1), UU No. 5 Tahun 1984 tentang Perindustrian. Pasal 1 ayat (3) UU No. 31 Tahun 1999 sebagaimana diubah dan ditambah dengan UU No. 21 Tahun 2001.

Pertanggungjawaban pidana korporasi menurut RUU KUHP, dianggap sebagai sumbangan pemikiran kriminologi. Meskipun hukum pidana Indonesia tidak asing lagi dengan konsep criminal responsibility of corporations, namun hampir 40 tahun sejak UUTPE ${ }^{13}$ ternyata belum ada yurisprudensi Indonesia tentang hal ini. Hal tersebut dapat ditafsirkan sebagai keseganan atau keragu-raguan kalangan sarjana hukum menerima korporasi sebagai subjek hukum pidana. Kemudian pemberlakuan rezim penjara setengah terbuka dan terbuka (half open and open prison) telah dipraktikkan di negara-negara Eropa seperti Belanda, Italia, Perancis, Jerman, dan Swedia. ${ }^{14} \mathrm{Hal}$ ini menunjukkan sikap yang paling mutakhir untuk meminimalisasi peran pidana penjara dalam pemidanaan dengan membangun rezim-rezim penjara baru yang lebih longgar, bahkan diupayakan untuk menghilangkan kesan angker rumah penjara dalam pelaksanaannya. Dalam UU Tindak Pidana Korupsi diperkenalkan suatu rumusan baru untuk mempermudah pembuktian, yakni dari delik materiil (Pasal 1 ayat (1) sub a menjadi Pasal 2 UU No. 31 Tahun 1999), menjadi delik formal dengan disisipkannya kata "dapat merugikan keuangan negara atau perekonomian negara", dan "dalam keadaan tertentu dapat dijatuhi pidana mati. ${ }^{15}$ Di dalam undang-undang ini melawan hukum mencakup perbuatan melawan hukum dalam arti formal maupun dalam arti materiil.

Demikian pula bila dilihat dari ancaman pidana, maka terdapat ancaman pidana penjara maupun denda sesuai dengan bobot delik termasuk kualifikasinya, yakni ancaman pidana yang ringan untuk pidana penjara 1 (satu) tahun dan denda maksimum Rp. 1.000.000.000 (satu miliar rupiah). Tindak pidana korupsi dalam undang-undang ini dinyatakan: Pertama, setiap orang yang secara melawan hukum melakukan perbuatan memperkaya diri sendiri atau orang lain atau suatu korporasi, yang dapat merugikan keuangan negara atau perekonomian negara, dipidana

\footnotetext{
${ }^{13}$ Sampai dengan 13 Mei 1995.

${ }^{14}$ Vicenzo Ruggiero, Mick Ryan, dan Joe Sim, Western European Penal System: A Critical Anatomy, SAGE Publications, London, 1955, hlm. 65.

${ }_{15}$ Andi Hamzah, Pemberantasan Korupsi Ditinjau dari Hukum Pidana, Pusat Studi Hukum Pidana Universitas Trisakti, Jakarta, 2002.
} 
penjara seumur hidup atau pidana penjara paling singkat 4 (empat) tahun dan paling lama 20 (dua puluh) tahun dan denda paling sedikit Rp. 200.000 .000 (dua ratus juta rupiah) dan paling banyak Rp. 1.000.000.000 (satu miliar rupiah); Kedua, dalam hal tindak pidana korupsi sebagaimana dimaksud dalam ayat (1) dilakukan dalam keadaan tertentu, pidana mati dapat dijatuhkan. Dalam perkembangannya tentang maksimalisasi penggunaan pidana denda tampak dari dapat dikenakannya kategori pidana denda yang lebih tinggi, daripada yang diancamkan terhadap orang perseorangan. Selain itu, terhadap delik-delik yang tidak diancam dengan pidana denda, khususnya apabila dilakukan oleh korporasi justru dijatuhkan pidana denda. Hal demikian dapat diketahui berdasarkan ketentuan Pasal 23 ayat (5) KUHP Belanda. ${ }^{16}$ Selain itu, pada RUU KUHP, maksimalisasi pidana denda dapat diketahui melalui semakin maraknya undang-undang yang bersifat administratif. Schaffmeister menyatakan, hukum pidana dewasa ini dituntut untuk memenuhi dua fungsi, yaitu penegakan norma-norma etis dan juga penegakan norma-norma pengatur lainnya yang non-etis, yang diperlukan demi pengaturan ketertiban kehidupan sosial. ${ }^{17}$

Tanda lain yang mencirikan maksimalisasi penggunaan pidana denda adalah diperkenalkannya model pengancaman dengan menggunakan kategorisasi. Model ini dimaksudkan untuk mempermudah diadakannya perubahan perundangundangan yang menyangkut besar ancaman pidana denda, mengikuti perkembangan perekonomian, terutama angka inflasi. KUHP Belanda dalam perumusan deliknya tidak menentukan besarnya denda tertentu, melainkan menentukan dalam buku pertama dengan kategorisasi, mulai lima ratus Gulden sampai satu juta Gulden. RUU KUHP, menentukan pula kategori terendah pidana denda (kategori I) maksimal sebesar Rp 1.500.000,00 (satu juta lima ratus ribu rupiah) dan kategori tertinggi (kategori VI) sebesar Rp 3.000.000.000,00 (tiga miliar rupiah). Kecenderungan penentuan pidana denda dengan merumuskannya secara kategoris dalam Buku Pertama RUU KUHP, sehubungan dengan pola jenis sanksi yang berhubungan dengan pola pembagian jenis pidana menurut KUHP, untuk kejahatan umumnya diancam dengan pidana penjara atau denda, sedangkan untuk pelanggaran diancam dengan pidana kurungan atau denda. ${ }^{18}$ Upaya memaksimalkan penggunaan pidana

${ }^{16}$ Jan Remmelink, Op.Cit., hlm. 488.

${ }^{17}$ Schaffmeister, Zongen Van Helden, Terjemahan P. Moeliono, Kekhawatiran Masa Kini, Citra Aditya Bakti, Bandung, 1994, hlm. 7.

${ }^{18}$ Barda Nawawi Arief, Bunga Rampai Kebijakan Hukum Pidana, Citra Aditya Bakti, Bandung, 1996, hlm 171172. RUU KUHP mengklasifikasikan tindak pidana yang sifatnya/bobotnya sangat ringan hanya dengan pidana 
denda dalam pemidanaan juga ditandai dengan adanya perkembangan penemuan model-model eksekusi pidana denda. Perkembangan ini terutama ditujukan untuk meningkatkan sifat nestapa dari pidana denda. Pidana denda yang semula oleh sebagian orang dirasakan tidak terlalu menakutkan, karena dapat diganti dengan kurungan, bilamana denda tidak dibayar, kini di dalam RUU KUHP dikenal sistem denda harian (day-fine). ${ }^{19}$

Uraian di atas membuktikan betapa pidana denda menjadi lebih menonjol dan memerlukan perhatian lebih dari yang selama ini. Persoalan yang krusial dari fenomena ini adalah, bahwa kecenderungan tersebut tidak saja memasuki stadia akademik, tetapi juga memasuki stadia perundang-undangan, walaupun dalam kenyataannya penggunaan pidana denda oleh hakim masih menyisakan permasalahan. Roeslan Saleh mengemukakan bahwa aktivitas pembuat undangundang pada mulanya adalah menetapkan peraturan-peraturan yang sebenarnya telah hidup di dalam masyarakat. Dalam perkembangan selanjutnya, tugas pembuat undang-undang adalah untuk mengadakan, mengarahkan serta mendorong perubahan dalam masyarakat, serta memberi sumbangan terhadap pembentukan perubahan masyarakat, sehingga pembentuk undang-undang harus mendahului perubahan masyarakat. ${ }^{20}$ Dengan pidana denda yang tinggi, sebagaimana direfleksikan dalam berbagai ketentuan undang-undang di luar KUHP, menunjukkan bahwa pembuat undang-undang ingin menjaga undang-undang agar dipatuhi, serta menjaga pula akibat-akibat dari dilarangnya norma perundang-undangan itu. Hal ini menyebabkan terdapat hubungan tertentu antara pembentuk undang-undang dan undang-undang di satu pihak, dengan hakim dan penegak hukum lainnya di pihak lain. ${ }^{21}$ Berkenaan dengan posisi pidana denda dalam konteks perkembangan pemidanaan, hal ini sangat tergantung dari hubungan antara pengancamannya dalam undang-undang dan penetapannya oleh hakim sebagai suatu keputusan pengadilan. Penerapan pidana denda dalam yurisprudensi tidak mencapai suatu perkembangan dibandingkan dengan pertumbuhan pidana denda dalam perundang-undangan.

denda (tunggal). Untuk delik berat diancam pidana penjara atau denda (alternatif) untuk delik sangat serius, diancam dengan pidana penjara saja (tunggal).

${ }^{19}$ R.A Koesnoen, Susunan Pidana dalam Negara Sosialis Indonesia, Sumur Bandung, Bandung, 1964, hlm 117. Dalam buku ini dikemukakan tentang denda harian ini. Dengan mengenakan denda, maka hakim bermaksud untuk menginsyafkan narapidana untuk menjadi lebih baik.

${ }^{20}$ Roeslan Saleh, "Melihat ke Belakang dan Menatap ke Depan dengan Memperkokoh Dasar Hukum yang Berlaku Hingga Kini dan di Waktu Akan Datang”, Seminar Kepolisian, Jakarta, 1996, hlm. 33.

${ }^{21}$ M. Arief Amrullah, Politik. Hukum Pidana dalam Perlindungan Korban Kejahatan Ekonomi di Bidang Perbankan, Bayumedia, Malang, 2007. 


\section{Rumusan Masalah}

Pertama, bagaimana formulasi pidana denda dalam hukum pidana positif?; Kedua, bagaimanakah penjatuhan pidana denda dalam praktik peradilan tindak pidana korupsi?; dan Ketiga, bagaimana seharusnya kebijakan formulasi pidana denda dalam upaya penanggulangan tindak pidana korupsi?

\section{Tujuan Penelitian}

Pertama untuk mendapatkan pemahaman yang lebih mendalam mengenai formulasi pidana denda dalam hukum pidana positif; Kedua, untuk ,mengetahui lebih mendalam mengenai penjatuhan pidana denda dalam praktik peradilan tindak pidana korupsi; dan Ketiga untuk mendapatkan yang lebih mendalam mengenai kebijakan formulasi pidana denda dalam upaya penanggulangan tindak pidana korupsi

\section{Metode Penelitian}

Metode penelitian yang digunakan dalam disertasi ini adalah metode penelitian yuridis normatif yang bersifat kualitatif dan komparatif. Metode yuridis normatif yang digunakan dalam penelitian ini adalah untuk menganalisis data yang mengacu kepada norma-norma yang terdapat dalam peraturan perundang-undangan dan putusan pengadilan. Metode yuridis normatif ini mengacu pula kepada penelitian yang mengarah kepada dasar filosofis pidana denda. Untuk itu dilakukan penelusuran literatur, termasuk di dalamnya putusan-putusan pengadilan..$^{22}$ Dari literatur dan yurisprudensi tersebut dapat dilihat realitas masa lampau. ${ }^{23}$

Metode penelitian hukum di atas dilakukan dengan pendekatan yang bersifat kualitatif. Metode yang demikian mengingat penelitian tidak terlalu mementingkan kuantitas datanya, tetapi lebih mementingkan kedalamannya. Hal ini dilakukan mengingat terjadi perubahan pandang terhadap pidana denda tidak digantungkan pada banyaknya putusan pengadilan. Penelitian ini dilakukan melalui penelitian kepustakaan atau dokumen peraturan perundang-undangan, buku, jurnal hukum,

${ }^{22}$ Norman K. Denzin dan Yvonna S. Lincoln, eds, Handbook of Qualitative Research, Sage Publication, London, 1994, hlm. 205.

${ }^{23}$ Ibid. 
dan berbagai putusan pengadilan yang berkaitan permasalahan penelitian ini. Hasil penelitian yang diperoleh melalui studi kepustakaan dianalisis secara kualitatif dengan pendekatan yuridis normatif.

\section{Hasil dan Pembahasan}

\section{Formulasi Pidana Denda dalam Hukum Pidana Positif}

Dalam Pasal 10 KUHP, pidana denda ditempatkan dalam kelompok pidana pokok sebagai urutan terakhir. Dalam konteks KUHP, pidana denda belum dianggap sebagai pidana dalam arti sesungguhnya. Di balik itu, pidana kebebasan, khususnya pidana penjara dianggap lebih tepat (dibanding pidana denda) untuk suatu budaya kekerasan, pidana denda dianggap tidak mampu memenuhi fungsinya. Pidana denda dalam KUHP, sangat dirasakan kurang memenuhi rasa keadilan masyarakat, karena nilai pembalasan tersebut tidak memenuhi rasa keadilan. Legislator yang berkaitan dengan pidana khusus, cenderung mengenakan ancaman pidana denda dalam jumlah yang tinggi, sudah tepat memperlakukan pidana dan tindakan dalam suatu norma pidana di dalam perundang-undangan. Perkembangan pidana denda yang tinggi dalam undang-undang tindak pidana khusus belum mendapatkan perhatian terutama tentang adanya alternatif pidana penjara dan pidana denda yang selalu ancamannya tidak pernah sama jumlahnya dalam perundang-undangan yang dibuat dalam masa yang sama. Pidana denda juga dapat dikatakan sebagai pidana gabungan atau sebagai pengganti dari kurungan yang tidak terbayar atau penggunaan pidana denda tunggal terhadap korporasi maupun sanksi denda yang dikumulasikan dengan tindakan khususnya yang terdapat dalam putusan peradilan tindak pidana korupsi. Fenomena ini merupakan suatu permulaan dari kedudukan dan reposisi sanksi denda sebagai sanksi yang penggunaannya mulai digemari oleh legislator. Formulasi kebijakan hukum pidana dalam undang-undang administrasi mengatur tentang pidana dan tindakan yang dikenal dengan double track system dan single track system. Dalam undang-undang administrasi juga disebutkan secara tegas pidana pokok, pidana tambahan, dan menentukan pula variasi sanksi meliputi kumulasi, alternatif, serta gabungan kumulasi dan alternatif. Mengenal pula tentang maksimal khusus dan minimal khusus, menentukan pidana tambahan dan secara nyata mengkualifikasi delik yakni kejahatan dan pelanggaran. 
Dalam perkembangan undang-undang administrasi yang memuat ketentuan pidana pada tahap pembentukan undang-undang tersebut sangat dipengaruhi oleh globalisasi di dalam masyarakat juga digunakannya hukum pidana dalam rangka menopang agar kelemahan pada prinsip-prinsip hukum administrasi dapat ditegakkan melalui hukum pidana. Dikarenakan dalam kenyataannya tidak dapat dihindari bahwa ternyata pidana penjara masih merupakan sanksi yang dominan. Dapat diketahui pula bahwa hukum administrasi itu berkembang karena suatu evolusi yang kompromistis dalam kehidupan pribadi, harta benda, dan perdagangan yang memerlukan sanksi pidana.

Namun demikian, legislator tidak pernah memperhitungkan bagaimana proses eksekusi terhadap pidana denda yang tidak terbayar, sehingga mengganggu efektifitas penerapan pidana denda itu sendiri. Oleh karenanya bila denda tidak dibayar maka mekanisme KUHP yang akan berlaku yakni dengan kurungan yang maksimum hanya delapan bulan. Dengan adanya ketentuan tersebut biasanya pelaku delik tindak pidana, akan selalu memilih pidana kurungan daripada nestapa membayar denda yang tinggi, sehingga dalam formulasi kebijakan hukum pidana sebaiknya legislator merubah model-model eksekusi itu menjadi penerapan pidana denda yang dijamin pelaksanaannya dengan membayar denda dari harta kekayaan pelaku maupun keluarganya atau orang lain, baik melalui cicilan maupun dengan cara yang lain. Walaupun dalam pelaksanaannya putusan-putusan hakim masih memperlihatkan bahwa apabila pidana denda yang tidak dibayar maka dapat diganti dengan kurungan. Pidana penjara seringkali dianggap terlalu berat jika dibandingkan dengan pidana denda. Pidana denda akan diusahakan semaksimal mungkin dan menjadi prioritas utama sebelum ditambah dengan pidana penjara. Penggunaan pidana denda mempunyai beberapa keuntungan dibandingkan dengan pidana penjara. Penggunaan pidana denda dapat menghindari biaya-biaya sosial yang dikeluarkan untuk memelihara penjara, menghindari penahanan yang tidak perlu, dan menghindari penyia-nyiaan tenaga kerja manusia yang tidak berguna di dalam penjara.

Pidana denda, mengandung nilai ekonomis yang tidak dimiliki oleh pidana penjara. Dengan lebih mengedepankan pidana denda daripada pidana penjara, terutama maksimalisasi kekayaan negara, kekayaan digambarkan dalam pengertian ekonomi dan bukan perhitungan moneter sederhana. Definisi kekayaan ini digunakan dengan memperhatikan hukum, bahwa fasilitas hukum lazimnya memperbanyak transaksi dengan berbagai macam cara. Hal ini bukan berarti bahwa 
pidana penjara sama sekali tidak menghasilkan pendapatan bagi negara tidak seperti pidana denda, tetapi biaya-biaya sosial pidana penjara jauh lebih besar daripada kalau mengumpulkan pidana denda dari seorang terdakwa yang mampu membayar. Untuk menetapkan dan menjatuhkan pidana harus diterapkan prinsip proporsionalitas. Prinsip ini bermakna bahwa sanksi yang dikenakan harus sesuai dengan beratnya pelanggaran yang telah dilakukan. Hal ini merupakan salah satu upaya untuk mencapai keadilan. Untuk itulah penggunaan denda harus terus didorong sebagai salah satu bentuk pendapatan bagi negara. Cara penghukuman pidana denda, mempunyai perspektif keadilan yakni pembayaran denda mudah dilaksanakan dan dapat direvisi bilamana ada kesalahan, pidana denda ini adalah sanksi yang menguntungkan pemerintah karena pemerintah tidak mengeluarkan biaya untuk pemidanaan. Pidana denda mudah dilihat, diatur, dan tidak mengakibatkan tercelanya terpidana dan memberikan kesempatan bagi terpidana untuk memperbaiki hidupnya, pidana denda dapat menjadi penghasilan bagi negara. Dengan mengacu pada tujuan pemidanaan, sebagaimana yang dikemukakan oleh para ahli hukum pidana maupun yang tercantum dalam RUU KUHP, oleh karenanya pidana denda seharusnya dapat dirasakan sifat nestapa dengan keharusan membayar dendanya.

\section{Penjatuhan Pidana Denda dalam Praktik Peradilan Tindak Pidana Korupsi.}

Nilai pembalasan terhadap jumlah denda yang sangat ringan, tercantum di dalam KUHP. Untuk kejahatan hanya terdapat pada Pasal 403 KUHP. Untuk pelanggaran hanya terdapat pada Pasal 40 KUHP. Dari keseluruhan pasal untuk kejahatan maksimum dendanya hanya berkisar Rp. 900 (sembilan ratus rupiah) dan ancaman denda maksimum adalah Rp 150.000 (seratus lima puluh ribu rupiah) hanya terdapat dalam Pasal 251. Pasal ini mengatur tentang kesengajaan tanpa ijin pemerintah menyimpan atau memasukkan ke Indonesia keping-keping atau lembaran perak dan 403 KUHP untuk pelanggaran, denda maksimum Rp 225 (dua ratus dua puluh lima ribu rupiah) dan $\mathrm{Rp} 7.500$ (tujuh ribu lima ratus rupiah) terdapat pada Pasal 568 dan 569 KUHP. Walaupun pidana denda melalui ini telah disesuaikan dengan dikalikan lima belas kali dengan nilai mata uang pada saat itu sebagaimana diatur dalam Pasal 1 ayat (1) Perpu No. 18 Tahun 1960, tetapi hal tersebut dirasakan masih belum memenuhi keadilan. Dikarenakan sudah tidak sesuai lagi dengan nilai inflasi terkini. Hal inilah yang membuat penerapan pidana denda tidak berjalan 
efektif, sehingga hakim cenderung lebih memilih menggunakan pidana penjara yang secara langsung dapat dirasakan efek nestapanya oleh pelaku.

Kecenderungan legislator untuk selalu menggunakan sanksi denda yang tinggi di dalam undang-undang pidana di luar KUHP, baik dialternatifkan dengan penjara maupun dikumulasikan dengan denda maupun ganti kerugian semata-mata bertujuan untuk memberikan efek jera bagi pelaku. Hal ini dapat dilihat pada UU No. 20 Tahun 2001 yang mengenakan minimal sanksi pidana penjara paling singkat adalah 1 (satu) tahun dan denda paling sedikit Rp 50.000.000 (lima puluh juta rupiah) dan maksimal pidana penjara paling lama 20 (dua puluh) tahun dan denda paling banyak Rp 1.000.000.000 (satu miliar rupiah). Pada UU No. 28 Tahun 1999 tentang Penyelenggara Negara yang Bersih dan Bebas dari Korupsi, Kolusi dan Nepotisme mengenakan pidana penjara paling singkat 2 (dua) tahun dan paling lama 12 (dua belas) tahun. Untuk pidana denda paling sedikit Rp 200.000.000 (dua ratus juta rupiah) dan paling banyak Rp 1.000.000.000 (satu miliar rupiah). UU No. 5 Tahun 1997 tentang Psikotropika menentukan bahwa besaran sanksi denda maksimal Rp 5.000.000.000 (lima miliar rupiah) dan minimum Rp 20.000.000 (dua puluh juta rupiah). UU No. 22 Tahun 1997 tentang Narkotika menentukan pidana mati alternatif penjara seumur hidup, maksimal sanksi denda senilai Rp 7.000.000.000 (tujuh miliar rupiah) dan minimal Rp 1.000.000 (satu juta rupiah). UU No. 25 Tahun 2003 tentang Perubahan Atas UU No. 15 Tahun 2002 tentang Tindak Pidana Pencucian Uang menentukan sanksi pidana penjara paling lama adalah 15 (lima belas) tahun dan paling singkat 1 (satu) tahun. Untuk sanksi pidana denda minimal Rp 100.000 .000 (seratus juta rupiah) dan maksimal Rp 15.000.000.000 (lima belas milyar rupiah). UU No. 11 Tahun 1980 tentang Tindak Pidana Suap menentukan pidana penjara paling lama 5 (lima) tahun dan pidana denda maksimal Rp 15.000.000 (lima belas juta rupiah). UU No. 15 Tahun 2003 tentang Pemberantasan Tindak Pidana Terorisme menentukan maksimal pidana denda sebesar Rp 1.000.000.000.000 (satu triliun rupiah). UU No. 10 Tahun 1995 tentang Kepabeanan menentukan sanksi pidana penjara paling lama 8 (delapan) tahun dan denda paling banyak Rp 500.000.000 (lima ratus juta rupiah). Denda minimum Rp 125.000.000 (seratus dua puluh lima juta rupiah). UU No. 13 Tahun 2006 tentang Perlindungan Saksi dan Korban menentukan sanksi pidana penjara paling singkat adalah 1 (satu) tahun dan paling lama seumur hidup, dan sanksi pidana denda paling sedikit Rp 30.000.000 (tiga puluh juta rupiah) dan paling banyak Rp 500.000.000 (lima ratus juta rupiah). UU No. 23 Tahun 2004 tentang Penghapusan Kekerasan dalam 
Rumah Tangga menentukan sanksi pidana penjara paling lama 20 (dua puluh) tahun. Untuk pidana denda maksimal Rp 500.000.000 (lima ratus juta rupiah) dan minimum Rp 3.000.000 (tiga juta rupiah).

Hal yang sama juga terjadi pada beberapa pengaturan pidana denda dalam undang-undang administrasi. Pidana denda tumbuh dengan subur sebagai pidana alternatif maupun kumulatif. Pidana denda juga dapat dikatakan sebagai pidana gabungan atau sebagai pengganti dari kurungan yang tidak terbayar atau penggunaan pidana denda tunggal terhadap korporasi. Hal ini dapat dilihat pada UU No. 10 Tahun 1998 tentang Perubahan atas UU No. 7 Tahun 1992 tentang Perbankan yang menentukan pidana penjara paling lama 15 (lima belas) tahun dan paling singkat 1 (satu) tahun. Untuk denda maksimal Rp 200.000.000.000 (dua ratus milyar rupiah) dan minimal Rp 1.000.000.000 (satu miliar rupiah). UU No. 23 Tahun 1997 tentang Pengelolaan Lingkungan Hidup juga menentukan pidana penjara paling lama 15 (limabelas) tahun dan denda maksimal Rp 750.000 .000 (tujuh ratus lima puluh juta rupiah). Minimum denda adalah sebesar Rp 100.000 .000 (seratus juta rupiah). UU No. 8 Tahun 1995 tentang Pasar Modal menentukan pidana penjara paling lama 10 (sepuluh) tahun dan denda paling banyak Rp 15.000.000.000 (limabelas miliar rupiah). Denda minimumnya adalah Rp 1.000.000.000 (satu miliar rupiah). UU No. 5 Tahun 1999 tentang Larangan Praktek Monopoli dan Persaingan Usaha Tidak Sehat menentukan sanksi pidana denda minimum Rp 1.000.000.000 (satu miliar rupiah) dan denda maksimum Rp 100.000.000.000 (seratus miliar rupiah).

UU No. 41 Tahun 1999 tentang Kehutanan menentukan pidana penjara paling lama 5 (lima) tahun dan denda maksimal Rp 10.000.000.000 (sepuluh miliar rupiah). Denda minimum Rp 50.000.000 (lima puluh juta rupiah). Dalam UU No. 22 Tahun 2001 tentang Minyak dan Gas ditentukan pula bahwa pidana penjara paling lama 6 (enam) tahun dan denda maksimal Rp 60.000.000.000 (enam puluh miliar rupiah). Denda minimum Rp 10.000.000.000 (sepuluh miliar rupiah). UU No. 2 Tahun 2004 tentang Penyelesaian Perselisihan Hubungan Industrial, menentukan pidana penjara paling lama 6 (enam) bulan dan denda maksimal Rp 50.000.000 (lima puluh juta rupiah), serta denda minimum Rp 3.000.000 (tiga juta rupiah). Dalam UU No. 23 Tahun 2006 tentang Administrasi Kependudukan ditentukan bahwa pidana penjara paling lama 10 (sepuluh) tahun dan denda paling banyak Rp 1.000.000.000 (satu miliar rupiah). Denda minimum Rp 50.000 (lima puluh ribu rupiah). 
Dalam UU No. 24 Tahun 2007 tentang Penanggulangan Bencana ditentukan pidana penjara paling lama 20 (dua puluh) tahun dan denda paling banyak Rp 12.000.000.000 (duabelas miliar rupiah). Denda minimumnya adalah Rp 2.000.000.000 (dua miliar rupiah). UU No. 28 Tahun 2007 tentang Perubahan Ketiga atas UU No. 6 Tahun 1983 tentang Ketentuan Umum dan Tata Cara Perpajakan menentukan pidana penjara paling lama 1 (satu) tahun dan denda paling banyak Rp 1.000.000.000 (satu miliar rupiah), serta denda minimumnya sebesar Rp 25.000.000 (dua puluh lima juta rupiah). Terakhir, UU No. 10 Tahun 2008 tentang Pemilihan Umum Anggota Dewan Perwakilan Rakyat, Dewan Perwakilan Daerah, dan Dewan Perwakilan Rakyat Daerah menentukan pidana penjara paling lama 48 (empat puluh delapan) bulan dan denda paling banyak Rp 10.000.000.000 (sepuluh miliar rupiah). Denda minimum Rp 3.000.000 (tiga juta rupiah)

Undang-undang pidana khusus maupun undang-undang administrasi, legislator tidak mempunyai standar untuk menentukan minimal ataupun maksimal pidana denda dan pidana penjara. Setiap undang-undang yang dibuat memiliki aturan tersendiri tentang berapa maksimal dan minimal pidana denda yang akan dikenakan. Namun demikian, semangat para legislator menentukan pidana denda yang tinggi di luar KUHP adalah suatu kemajuan. Hal ini ditujukan untuk memberikan efek nestapa dan jera bagi pelaku. Walaupun dalam pelaksanaannya putusan-putusan hakim masih memperlihatkan penerapan pidana denda dibawah ketentuan minimum undang-undang, termasuk apabila pidana denda yang tidak dibayar maka dapat diganti dengan kurungan.

\section{Kebijakan Formulasi Pidana Denda dalam Upaya Penanggulangan Tindak Pidana Korupsi}

Kebijakan penanggulangan korupsi di Indonesia telah dilakukan sejak zaman kemerdekaan. Kebijakan ini lebih banyak dicurahkan pada pendekatan penal. Hal ini terlibat secara historis dari perangkat hukum yang dikeluarkan pemerintah Indonesia. Kebijakan ini dilakukan melalui berbagai pembaharuan hukum pidana yang sudah dimulai sejak terbitnya Undang-Undang Nomor 1 Tahun 1946. Dalam perkembangannya, berbagai undang-undang telah diundangkan untuk melakukan perubahan-perubahan yang diperlukan agar sesuai dengan kebutuhan masyarakat dan tuntutan zaman. Pembaharuan hukum pidana dapat dilakukan melalui dua 
jalur yaitu pembuatan RUU KUHP dan pembaharuan perundang-undangan pidana.

Dalam RUU KUHP kecenderungan untuk menaikkan jumlah pidana denda yang termuat di dalam Kategori VI yaitu sejumlah Rp 3.000.000.000 (tiga miliar rupiah). Tingginya jumlah pidana denda dalam RUU KUHP bertujuan untuk memberikan efek jera dan nestapa bagi pelaku. Dalam konsep RUU KUHP juga telah dirumuskan alternatif pengganti dari pidana denda yang tidak dapat dibayar, yakni pidana pengawasan atau pelayanan masyarakat (social services). Dengan adanya alternatif pidana denda tersebut maka pembayaran denda lebih dipertegas kemungkinan eksekusinya. Walaupun telah banyak aturan-aturan dan upaya-upaya untuk menanggulangi tindak pidana korupsi melalui denda yang tinggi, tetapi selama ini hakim masih enggan menerapkan pidana denda. Dalam praktik pemidanaan di pengadilan saat ini ternyata pidana perampasan kemerdekaan masih merupakan pilihan utama para hakim dalam memutuskan suatu pemidanaan. Pidana denda mampu memberikan banyak segi keuntungan dan rasa keadilan, yaitu, mudah dilaksanakan dan direvisi apabila ada kesalahan, merupakan jenis hukuman yang menguntungkan pemerintah, hukuman denda tidak membawa atau tidak mengakibatkan tercelanya nama baik atau kehormatan seperti yang dialami terpidana. pidana denda akan membuat lega dunia perikemanusiaan. Pidana denda juga akan menjadi penghasilan bagi negara.

Terkait dengan upaya menanggulangi tindak pidana korupsi, seharusnya pidana denda yang belum dapat dibayar juga harus dapat diangsur dan tidak boleh diganti dengan pidana kurungan pengganti. Dalam kenyataannya, hal ini berlawanan dengan keadaan sekarang. Melalui pandangan hakim yang tercermin dalam putusannya, dengan berpedoman pada hukum positif semata-mata, dalam perundang-undangan selalu disediakan formulasi dengan pidana kurungan terhadap pidana denda yang tidak terbayar. Hal inilah yang merupakan salah satu penyebab pelaksanaan pidana denda tidak efektif dalam praktik peradilan. Oleh karenanya jarang sekali pidana denda diterapkan secara tunggal. Dengan demikian dapat dikatakan bahwa betapapun tingginya pidana denda yang dijatuhkan, apabila terpidana tidak mampu membayar, konsekuensinya hanyalah dikenakan pidana kurungan yang maksimumnya hanya 6 (enam) bulan atau dapat paling lama 8 (delapan). Dalam hal pelaku korupsi melakukan tindak pidana korupsi yang dapat menghasilkan keuntungan yang banyak, maka pelaku masih tetap dapat menikmati 
hasilnya dengan tidak perlu khawatir harta bendanya akan dipergunakan untuk membayar denda karena bisa diganti dengan pidana penjara yang ringan.

Upaya penanggulangan korupsi melalui kebijakan perundang-undangan dan penegakan hukum pidana sebenarnya telah lama dilakukan. Namun harus diakui bahwa korupsi itu masih tetap ada dan sulit untuk diberantas. Hal itu disebabkan korupsi berkaitan dengan berbagai kompleksitas masalah lainnya seperti masalah sikap mental, moral, pola atau sikap hidup dalam kehidupan sosial, masalah kebutuhan atau tuntutan ekonomi, struktur atau sistem ekonomi, struktur budaya atau politik, masalah peluang yang ada di dalam mekanisme pembangunan dan sekaligus kelemahan birokrasi atau prosedur administrasi, termasuk sistem keuangan dan pelayanan umum. Mengingat kompleknya masalah tersebut, kebijakan penanggulangan korupsi memang tidak dapat diatasi secara fragmentaris, tetapi harus dilakukan secara utuh dan integral. Pendekatan struktur dan substantif tidak akan berhasil jika tidak diikuti pendekatan budaya dan etika dari penegak hukum itu sendiri yang sering terkontaminasi korupsi lanjutan.

Dengan adanya pengaturan pidana denda yang tinggi dalam Undang-Undang Pencegahan Tindak Pidana Korupsi, setidaknya memberikan sumbangan dalam mengurangi terjadinya tindak pidana korupsi, walaupun undang-undang tersebut mengatur juga tentang pidana tambahan sebagaimana Pasal 18 Undang-Undang Nomor 31 Tahun 1999 tentang Pemberantasan Tindak Pidana Korupsi, sebagaimana diubah menurut Undang-Undang Nomor 20 Tahun 2001. Dengan belum adanya kebijakan legislatif mengenai pelaksanaan pidana denda sebagaimana yang diatur dalam aturan umum KUHP, maka tidak akan banyak artinya kebijakan untuk menaikkan jumlah ancaman pidana denda di luar KUHP tanpa adanya perubahan di dalam KUHP. Dalam menetapkan kebijakan legislatif pidana denda di masa depan yang berhubungan dengan pelaksanaan pidana denda perlu dipertimbangkan, sistem penetapan jumlah atau besarnya pidana denda, batas waktu pelaksanaan pidana denda, tindakan-tindakan paksaan yang diharapkan dapat menjamin terlaksananya pembayaran denda dalam hal terpidana tidak dapat membayar dalam batas waktu yang telah ditetapkan, pelaksanaan pidana denda dalam hal-hal khusus, dan pedoman atau kriteria untuk menjatuhkan pidana denda.

Mengenai penetapan jumlah pidana denda, diperlukan perumusan dalam kebijakan legislatif. Hal ini mengingat pidana denda berbeda dengan jenis pidana pokok lainnya di mana pidana denda merupakan jenis pidana yang bernilai uang 
dan mempunyai nilai ekonomis, sehingga harus dilaksanakan pidana denda secara tuntas. Oleh karena itu, dalam menetapkan dan menerapkan pidana denda harus diterapkan prinsip proporsionalitas. Prinsip ini bermakna bahwa sanksi yang dikenakan harus sesuai dengan beratnya pelanggaran yang telah dilakukan. Hal ini merupakan salah satu upaya untuk mencapai keadilan. Adanya beberapa kelemahan kebijakan untuk menanggulangi tindak pidana korupsi saat ini mengharuskan lahirnya kebijakan baru. Atas dasar pemikiran inilah maka tahap formulasi kebijakan pidana oleh legislatif harus dilakukan perubahan terhadap undang-undang korupsi tersebut, sehingga tujuan pengenaan pidana penjara, denda, dan tindakan sebagaimana yang telah diatur di dalam undang-undang korupsi tersebut memenuhi keinginan dan tujuan pemidanaannya yakni selain memberikan efek jera, nestapa, dan perlindungan tetapi juga memberikan jaminan pengembalian aset negara dari terpidana korupsi dapat dilaksanakan secara efisien dan efektif.

Pidana denda sebagai hukum sanksi, harus mendapatkan formulasi yang tepat dalam pelaksanaannya yang disesuaikan dengan efisiensi. Didasarkan pula pada rasionalitas yang tetap bernuansakan falsafah pemidanaan, yaitu keseimbangan, keharmonisan jiwa lahir dan batin dengan pengaruh falsafah, ajaran, pemikiran para ahli pidana di dunia dari masa ke masa, bahkan beberapa sistem hukum yang berkembang dalam suatu masyarakat adat, dengan ganti kerugian sebagai pemenuhan kewajiban adat adalah kepuasan masyarakat terlepas dari intervensi negara atau sistem peradilan pidana atau berhubungan dengan sistem tersebut. Demikian pula pengaruh hukum Islam, dengan pengenaan diyat maupun denda terhadap kejahatan yang mengakibatkan kematian atau pelukaan yang tidak disengaja dengan pembayaran diyat, atau berpuasa dan atau dimaafkan oleh korban ataupun keluarga korban, bahkan pembayaran diyat dibebankan pada kekayaan keluarga terpidana. Hal demikian menunjukkan diterimanya restorative justice dalam pembaharuan hukum pidana, terutama tentang pidana denda sebagai bentuk pemidanaan yang berorientasi kepada keseimbangan.

\section{Penutup}

Pertama, formulasi pidana denda dalam hukum pidana positif belum sesuai dengan modernisasi pemidanaan. Pengaturan pidana denda di dalam hukum pidana positif tertinggal jauh bilamana dibandingkan dengan pemberlakuan denda di berbagai negara. 
Kedua, penerapan pidana denda dalam praktik peradilan tindak pidana korupsi dapat dikatakan belum sesuai dengan upaya penanggulangan tindak pidana korupsi. Dalam perkara korupsi hakim telah mengenakan ancaman pidana penjara yang tinggi bagi pelaku korupsi. Pada peradilan tindak pidana korupsi seluruh perkara terbukti secara sah dan meyakinkan. Denda yang dikenakan bagi pelaku tindak pidana korupsi telah sesuai dengan ketentuan denda yang ada di dalam undang-undang tindak pidana korupsi. Walaupun sebagian besar seluruh perkara korupsi terbuksi secara sah dan meyakinkan, terutama dalam pengadilan tindak pidana korupsi oleh komisi pemberantasan korupsi, tetapi sulitnya mengeksekusi sanksi denda dan ganti kerugian dalam tindak pidana korupsi menjadi masalah yang belum dapat diselesaikan. Adapun masalah yang kerap kali terjadi terhadap pembayaran pidana denda dan penagihan uang pengganti bagi terpidana selalu dengan alasan terpidana tidak mampu membayar uang pengganti tersebut.

Ketiga, formulasi kebijakan pidana denda dalam upaya penanggulangan tindak pidana korupsi, dilakukan secara efisien atas dasar rasionalitas. Kebijakan hukum pidana dilakukan melalui pembaharuan terhadap undang-undang korupsi yang ada. Guna pencapaian tujuan pengenaan pidana penjara secara selektif, penguatan penerapan pidana denda, dan tindakan sebagaimana yang telah diatur di dalam undang-undang korupsi, tersebut sehingga memenuhi keinginan dan tujuan, memberikan efek jera, nestapa, dan perlindungan tetapi juga memberikan jaminan pengembalian aset negara dari terpidana korupsi dan dapat dilaksanakan secara efisien dan efektif. Adanya upaya luar biasa bagi penanggulangan tindak pidana korupsi. Peradilan diberikan keleluasaan untuk mengembangkan peradilan perdamaian terhadap perkembangan yang menggejala dari restrorative justice yang menitikberatkan pada rekonsiliasi dan perdamaian.

\section{Daftar Pustaka}

Agus Santoso, Muhari, Paradigma Baru Hukum Pidana, Averroes Press, Malang, 2002.

Arief Amrullah, M., Politik Hukum Pidana dalam Perlindungan Korban Kejahatan Ekonomi di Bidang Perbankan, Bayumedia, Malang, 2007.

D. Levitt, Steven, "Incentive Compatibility Constraints as an Explanation for the Use of Prison Sentences Instead of Fines," International Review of Law and Economics, Volume 17, Juni 1997. 
Hamzah, Andi, Sistem Pidana dan Pemidanaan di Indonesia dari Retribusi ke Reformasi, Pradnya Paramita, Jakarta, 1986.

- Pemberantasan Korupsi Ditinjau dari Hukum Pidana, Pusat Studi Hukum Pidana Universitas Trisakti, Jakarta, 2002.

K. Denzin, Norman, dan Yvonna S. Lincoln, eds, Hanbook of Qualitative Research, Sage Publication, London, 1994.

Kanter, E.Y dan S.R Sianturi, Asas-Asas Hukum Pidana di Indonesia dan Penerapannya, Alumni, Jakarta, 1982.

Koesnoen, R.A., Susunan Pidana dalam Negara Sosialis Indonesia, Sumur Bandung., Bandung, 1964.

Muladi dan Barda Nawawi Arief, Teori-Teori dan Kebijakan Pidana, Alumni, Bandung, 1992.

Nawawi Arief, Barda, Bunga Rampai Kebijakan Hukum Pidana, Citra Aditya Bakti, Bandung, 1996.

R. Blad, John, Hans van Mastright dan Niels A Uildriks, Social Problem and Criminal Justice, Medelingen van het Juridisch Institut van de Erasmus Universuteit Rotterdam, Rotterdam, 1987.

Remmelink, Jan, Hukum Pidana: Komentar atas Pasal-Pasal Terpenting dalam Kitab Undang-Undang Hukum Pidana Belanda dan Padanannya Dalam Kitab UndangUndang Hukum Pidana Indonesia, PT Gramedia, Jakarta, 2003.

Ruggiero, Hicenzo, Mick Ryan, dan Joe Sim, Western European Penal System: A Critical Anatomy, SAGE Publications, London, 1955.

Saleh, Roeslan, “Melihat ke Belakang dan Menatap ke Depan dengan Memperkokoh Dasar Hukum yang Berlaku Hingga Kini dan di Waktu Akan Datang", Seminar Kepolisian, Jakarta, 1996.

Schaffmeister, Zongen Van Helden, Terjemahan P. Moeliono, Kekhawatiran Masa Kini, PT Citra Aditya Bakti, Bandung, 1994.

Sudarto, Hukum Pidana dan Pembangunan Masyarakat, Sinar Baru, Bandung, 1983.

Sutherland dan Cressey, The Control Crime, New York, 1960.

Waldfogel, Joel, "Are Fines and Prison Terms Used Efficiently? Evidence on Federal Fraud Offenders," Journal of Law and Economics, Volume 35, April, 1995.

Mahkamah Agung Republik Indonesia, Surat Edaran Mahkamah Agung Republik Indonesia (SEMARI) Tanggal 3 September 1975.

Depattemen Hukum dan Hak Asasi Manusia, RUU KUHP 2008, 